\title{
Major Volatile Compounds Analysis Produced from Mezcal Fermentation Using Gas Chromatography Equipped Headspace (GC-HS)
}

\author{
Melchor Arellano, Anne Gschaedler and Montserrat Alcazar \\ Research and Assistance Center for Technology and Design in the State of Jalisco, \\ Mexico
}

\section{Introduction}

Alcoholic beverages are produced from a variety of raw materials, principally fruits and cereals. Various microorganisms are used to ferment the sugars present in the must. Fermentation can be making using either the addition of specific microorganisms or spontaneous fermentation from naturally occurring microorganisms. Both, the microorganisms and the raw material affect the volatile compounds that are produced, and these volatile compounds are responsible for the aroma and unique taste of these beverages (Nykanen. 1983, Moreno. 2009).

In Mexico, alcoholic beverages produced during prehispanic times were used in religious rituals, as food, and for medicine (Lappe . 2008). Agave or "magueys" are used as principal raw material to produced alcoholic beverages. Since agaves grow best in arid and semiarid areas, they thrive in Mexico, where $45.3 \%$ of the land is semiarid. The Agave includes 20 genera, and the agave genus has 300 species, of which 200 species are indigenous to Mexico. The Mexican state of Oaxaca has the highest number of agave species (Valenzuela. 2007, Vázquez. 2007, Peña. 2004, SAGARPA 2004).

Agave species are used to produce both distilled and non-distilled alcoholic beverages, including: Tequila, mezcal, bacanora and raicilla, the first three has origin appellation mean only some places has the license to the production (www.impi.gob.mx). Another beverage is pulque a non-distilled alcoholic beverage (Lappe. 2008, Lachenmeier. 2006).

\section{Mezcal process}

Alcoholic beverages distilled from agave are produced in 6 stages: agave harvesting, cooking, milling, fermentation, distillation and aging, in the case of tequila, mezcal and bacanora in the official Mexican laws, the stages and other characteristics in the process are mentioned and most be followed for the factories (NOM-006-SCFI-1994 1994, SCFI 1997, SCFI 2004). The length of aging determines the type of mezcal: silver, reposado or añejo. While mezcal, tequila, raicilla and bacanora are produced using a similar process, they differ in the raw material used and the processing materials (equipment) and conditions. The next section briefly explains the mezcal process (figure 1). 


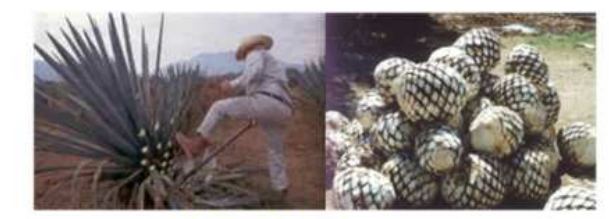

Harvesting
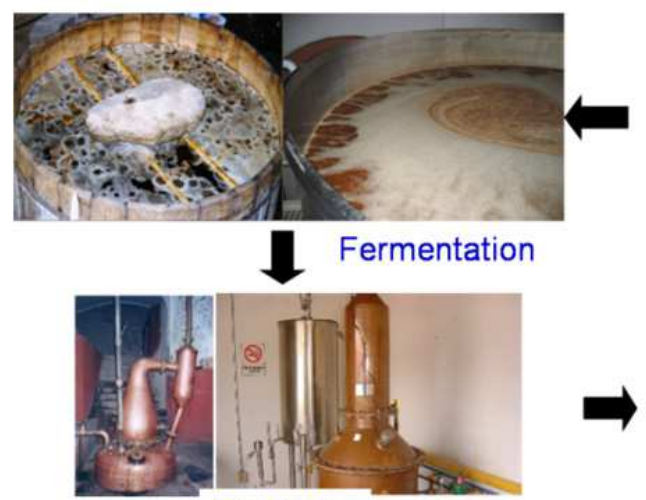

Distilation

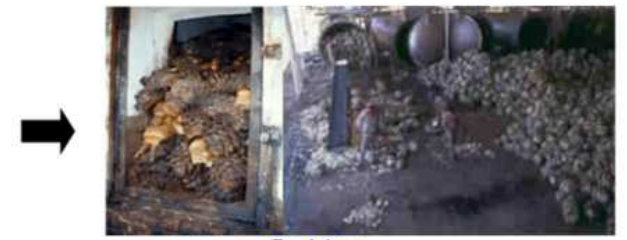

Coking

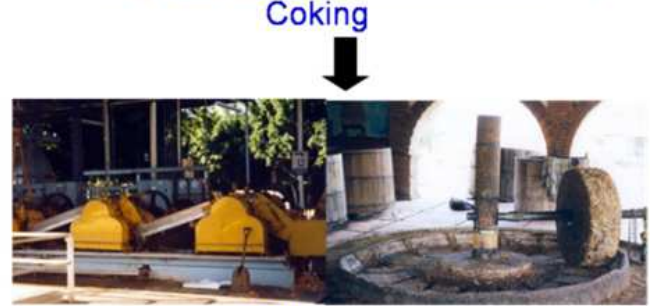

Milling

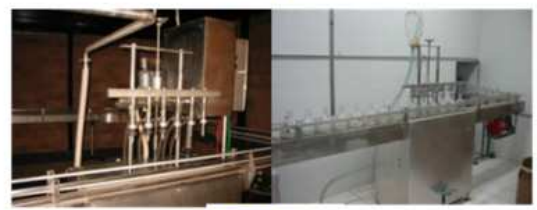

Bottling

Fig. 1. Mezcal processes.

\subsection{Harvesting the agave}

The raw material for mezcal is Agave. In Mexico, different alcoholic beverages are produced from different agave species. Tequila is produced from Agave tequilana Weber blue variety, bacanora from $A$. angustifolia and raicilla from A. inaequidens. Mezcal is produced from a variety of different species, depending on the location where it is produced. A. angustifolia, A. potatorum and A. karwinskii are principally used in Oaxaca State; A. durangensis in Durango State; A. salmiana in San Luis Potosí, Guanajuato and Zacatecas States; A. cupreata in Guerrero; and finally, A. angustifolia is used in Tamaulipas State (SCFI 1997, Lappe. 2008).

The agave plant is grown for 5 to 9 years before it is harvested. After harvesting, the leaves stripped off in a process called "jimado" collecting the heart or "piña", which weighs from 25 to $100 \mathrm{~kg}$ depending on the agave species. Finally the agave piñas are transported from the fields to the mezcal factory.

\subsection{Cooking}

Since agaves contain oligofructans (López. 2003), they must be hydrolyzed to obtain fermentable sugars. This is done by cooking the agave piñas in ovens, after they have been cut into two to four pieces. There are different types of ovens: autoclaves, room ovens (or "mamposteria") and soil ovens. In the soil oven, the cooking time and temperature are not controlled, which affects the amount of hydrolysis. For room ovens and autoclaves, the temperature and time are controlled and the hydrolysis is uniform. 


\subsection{Milling}

After cooking, the agave piñas are crushed with wood or steel mallets, or in a rudimentary mill using a large stone wheel $1.3 \mathrm{~m}$ in diameter and $0.5 \mathrm{~m}$ thick. The stone wheel is pulled by animals around a circular pit, crushing the cooked agave. The agave juice and the bagasse are collected and placed in fermentation tanks. Some factories have recently begun to use mills similar to those used in the sugar industry but smaller. In this case, water is added and the bagasse is separated, and only the agave juice is placed in the fermentation tank.

\subsection{Fermentation}

Mezcal factories start fermentation after the agave juice and the bagasse have been put into the fermentation tank; either by adding specific yeast, or by allowing the microorganisms present in the wort to ferment the juice spontaneously. Water is added as the temperature increases or an ethanol smell is detected (the quantity of water in the majority of factories is not precise). When yeast is added the fermentation last between 2 to 4 days, and spontaneous fermentation requires 2 or 3 weeks. The fermentation tanks are open and are fabricated from wood, stone, animal skins, or steel.

\subsection{Distilling}

After fermentation, the wort (agave juice and bagasse) is collected and put into the distillation equipment. Distillation separates ethanol and volatile compounds. The distillation is done in a pot still and rectifying column consisting of a kettle to hold the fermented wort and a condenser or a plate heat exchanger. Some factories use a steam coil to heat the wort, but most heat the kettle in a stove. Mezcal is distilled twice. In the first distillation, the alcohol concentration is between 20 to $40 \%$ by volume, after removing the first (heads) and last extraction (tails). The second distillation brings the concentration to 45 to $60 \%$ by volume.

\subsection{Aging}

The maturation step is not mandatory and the white mezcal (silver) may be bottle at 35 to $50 \%$ alcohol volume. But, some factories put the mezcal in oak barrels for at least 2 months then the mezcal is called "mezcal reposado", and if the time is more than a year is called "mezcal añejo". The alcoholic degree is adjust to the level wanted.

\section{Volatile compounds produced in mezcal}

The aroma and taste of alcoholic beverages are critical to their acceptance by consumers, and the primary determinants of aroma and taste are volatile compounds. For mezcal, some of the volatile compounds are specified by Mexican laws (SCFI 1997), including methanol, higher alcohols (fusel alcohols), and the compounds that influence volatile acids like acetic acid. These specifications are shown in table 1.

Volatile compounds are produced throughout all mezcal production stages. Some derived directly from the raw material, but most of them are produced during fermentation, and, to 
a lesser extent, during maturation, distillation and cooking (table 2). As was mentioned, the higher alcohols and methanol are produced in greater amounts than other volatile compounds like esters, aldehydes, ketones, carbonyls, acids, furans, and terpenes. More than 150 compounds have been found in tequila, and together they give tequila its characteristic aroma (Benn and Peppard. 1996). While the interaction between agave and yeast is very important, it is not completely understood, and more work is needed to elucidate how the agave juice influences the behavior of the yeast during fermentation. This will facilitate better control of the aroma in distilled agave beverages (De León. 2006, Molina. 2007, Alcázar-Valle. 2011). Since these volatile compounds are very important, some of their characteristics will be discussed.

Specification

Minimum concentration
Maximum concentration

$\%$ alcohol by volume at $20^{\circ} \mathrm{C}$

36.0

55.0

Dry extract $\mathrm{g} / \mathrm{l}$

0.2

10.0

Milligrams per 100 cubic centimeters referred at

alcohol anhydrous

Total acid (as acetic acid)

0.00

100.0

170.0

Higher alcohols $\mathrm{mg} / 100 \mathrm{ml}$

100.0

400.0

Methanol mg/100 ml

300.0

Table 1. Mezcal specifications under Mexican Laws (SCFI 1997).

\begin{tabular}{cccccc}
\hline Agave & Cooking & Fermentation & Distillation & Aging \\
\hline \multirow{2}{*}{ Mezcal } & $\begin{array}{c}\text { Terpenes, } \\
\text { fatty acids, } \\
\text { saponins. }\end{array}$ & no data & $\begin{array}{c}\text { Higher alcohols, } \\
\text { esters, aldehydes, } \\
\text { terpenes, furans. }\end{array}$ & $\begin{array}{c}\text { Acetals, acids, } \\
\text { alcohols, ketones, } \\
\text { aldehydes, esters, } \\
\text { phenols, furans, } \\
\text { terpenes. }\end{array}$ & no data \\
& & & & \\
\hline
\end{tabular}

Table 2. Some of the volatile compounds generated in mezcal production (Peña. 2004, Molina. 2007, Alcázar-Valle. 2011).

\subsection{Higher alcohols}

The higher alcohols have strong aroma including: 1-propanol, 2-methyl-1-propanol (isobutanol), 1-butanol, 2-methyl-1-butanol (amyl alcohol), and 3-methyl-1-butanol (isoamyl alcohol). These compounds are frequently found in alcoholic beverages, and can be produced from amino acids by catabolic or anabolic reactions. The catabolic reaction starts with a deamination reaction followed by a decarboxylation to produce an aldehyde, which is finally catalyzed to alcohol by an alcohol dehydrogenase enzyme (Table 3). The other way is during the amino acid anabolism, when there are not enough amines in the media to produce amino acids. The $\alpha$-ketoacids are decarboxylated producing aldehydes, which are then transformed to higher alcohols (Arrizon. 2001). 


\begin{tabular}{cccc}
\hline Amino acid & a-ketoacid & Aldehyde & Higher alcohol \\
\hline $\begin{array}{c}\text { Threonine or } \\
\text { metionine }\end{array}$ & a-ketobutyrate & Propilaldehyde & 1-propanol \\
Valine & a-ketoisovalerate & a-hidroxy-isovaraldehyde & Isobutylic \\
Leucine & a-ketoisocaproate & Isovaraldehyde & Isoamylic \\
Isoleucine & $\begin{array}{c}\text { a-keto- } \beta \text {-methyl- } \\
\text { valeric }\end{array}$ & $\begin{array}{c}\text { a-hidroxy- } \\
\text { isocaprylaldehyde }\end{array}$ & Amilic \\
\hline
\end{tabular}

Table 3. Biosynthesis of higher alcohol (Berry. 1987, Arrizon. 2001).

\subsection{Methanol}

Methanol is produced during the cooking stage of the mezcal process. Agave contains pectin with methoxyl groups, which are broken by the high temperature in the ovens. Some yeast has a pectin-methyl-esterase enzyme, which splits the methoxyl groups from the pectins and produces methanol during the fermentation (Berry. 1987).

\subsection{Esters}

Esters give fruitlike flavors and aromas to beverages. They have a low odor threshold: only few milligrams can be detected. Production of esters is controlled by the enzyme, acylcoenzyme A, and depends on the fermentation conditions and the yeast species used. In tequila, 47 different esters compounds have been identified, and the majority is ethyl acetate. In mezcal, 18 different esters compounds have been identified, primarily ethyl acetate, ethyl hexanoate, ethyl octanoate, and 2-phenethyl acetate (Gshaedler. 2004, Molina. 2007, Nykanen. 1983).

Ethyl acetate is produced by the yeast, Saccharomyces cerevisiae, using the acetyl alcohol transferase enzyme. It links the acetate from the acetyl-coA with an ethanol molecule. The esters produced can be affected by esterases enzymes, because they hydrolyze the aliphatic and aromatic esters. These enzymes can hydrolyze lipids to obtain medium chain fatty acids (Moreno. 2009). Production of esters is related to the quantity of amino acids. When the nitrogen from the amino acids is high, fatty acids decrease and acyl transferase is not inhibited (Arrizon. 2001).

\subsection{Carbonyls}

Among the most important carbonyls are the ketoacids, which are essential for amino acid synthesis and for the higher alcohols, since the carbonyls are intermediaries when the aldehydes are produced by the yeast (Nykanen. 1983). When the yeast viability or the cell activity is decreased, the yeast produces more aldehydes, because the metabolic reactions stop and fermentation cannot be completed (Nykanen. 1983, Moreno. 2009). 
Acetaldehyde is the primary compound produced during alcoholic fermentation; the main biosynthesis is during the anabolic process by the pyruvate decarboxylase enzyme. Aldehydes are also produced during the maturation stage by oxidation of alcohols (Nykanen., 1983; Berry. 1987).

\subsection{Terpenes}

Terpenes are found in Agave in two classes: free or glycosylate (monoterpenes or sesquiterpenes). The monoterpenes are compounds with 10 carbon atoms. They have a strong aroma with a fruity or herbal odor. Previous works in agaves have found nine different terpenes in A. salmiana, eight in A. angustifolia, and 32 in A. tequilana Weber blue variety. During fermentation, the sesquiterpenes are hydrolyzed to monoterpenes by $\beta$ glycosidase enzyme produced by yeast. Moreover, some yeasts like Saccharomyces cerevisiae, Torulaspora delbruckii and Kluyveromyces lactis, have enzymes that transform a monoterpenes into one another. During wine and beer production, these changes give aromatic differences to the beverages (Peña. 2004, King. 2000, Takoi. 2010).

Mezcal studies have found terpenes including: $\alpha$-terpineol, cintronellol, linalool, oxide trans-linalool, farnesol, a-nerolidol, $\alpha$-terpinene and limonene, principally, but only in white mezcal, not during the process (Molina. 2007, De León. 2006).

\subsection{Furans}

The furans are a family of compounds that are produced during a thermal process. In mezcal they can be produced during either the cooking stage or distillation. The majority of the furan compounds are 2-furfuraldehyde and 5-hydroxymethhyl-2-furfuraldehyde. These are produced during thermal degradation of sugars (De León. 2006, Molina. 2007).

\section{Identification and quantification of volatile compounds in mezcal fermentation by gas chromatography}

Chromatography is a laboratory technique for separating mixtures in order to analyze their components. The chromatography bases are as follows: a sample is dissolved in a mobile phase and then the mobile phase is forced through an immobile, immiscible stationary phase. The compounds in the sample interact differentially with the stationary phase and are eluted with different retention time, separating the compounds in the sample (Skoog Doublas A. 1992). In gas chromatography (GC), the sample is vaporized and injected into the chromatographic column head. The elution is with an inert gas like helium or nitrogen which is non-reactive with the sample. In this method, there is no interaction between the sample compounds and the mobile phase. The sample characteristics must be understood in order to obtain the best separation of the compounds. All the compounds must be volatile at the injection temperature, because the gas chromatography column has a small diameter and a small particle can cover the injection system and obstruct the column (Kolb. 1997, Skoog. 1992).

For complex samples with solids or non-volatile compounds, it is necessary to first extract the components to others that can affect the system, but the sample needs to retain the original compounds as much as possible. Various methodologies have been developed to 
analyze complex samples including distilling, liquid-liquid separation and head-space injection systems. However, it must be understood how these techniques effect the sample in order to determine the composition of the original sample.

In mezcal fermentation, as was mentioned, the wort includes agave juice which contains sugars, fibers (bagasse), yeast, brown color and dusty. Therefore, it is not possible to do a direct injection. Some investigators have used different methods to analyze fermented agave juice to evaluate its composition during the fermentation.

\subsection{Extraction methodologies}

Extraction methodologies are described in the following sections.

\subsubsection{Solvents extraction}

The methodology most used in the analysis of food and beverages is solvents extraction. Solvents are added to the sample which does not react with the compounds in the complex mix (table 4). However, there are disadvantages to this method: it takes a long time to dissolve the components in the sample; and some non volatile compounds can be retained in the solvent. As a result, it is not possible to achieve 100\% extraction (Kolb. 1997, Núñez. 1986).

The selection of the solvents is very important, because the compounds to be extracted must all be miscible in them. The solvents properties including: dielectric constant in order to obtain the desired polarity, the boiling point, the miscibility and the purity must all be known. Sometimes it is important to use azeotropic solvents to obtain a more complete extraction process.

\subsubsection{Steam distillation}

This method is used when a pollution- free extraction is needed. It is often used when the compounds in the sample are volatile, immiscible with water, and have low steam pressure and high boiling point. The steam distillation is used principally for temperature sensitive materials like essential oils (table 4).

\subsubsection{Batch distillation}

Batch distillation is used when the components in the sample are water soluble and are more volatile than water. The sample is heated until it is near its boiling point. Then the volatile compounds vaporize in the distillation system and condensed with a refrigerant. With this methodology, it is possible to separate only the non-volatile compounds (left in the flask with the sample) and obtain the same volume initial adjusted with water. Solvents with a low boiling point may be used to reduce the temperature required (table 4).

\subsubsection{Head-space extraction}

There are other methods for analyzing compounds that don't require solvents for extraction. A sample of known weight and volume (liquid, solid, or liquid and solid mix), is put it in a closed vial, heated to the desired temperature, and maintained at that temperature while the 
volatile compounds are vaporized, until equilibrium is reached between the sample and the free space. Then the volatile compounds are taken and injected into the GC (static headspace), or an inert gas may be added to the vial to increase the pressure and a sample in the volatile section is taken (dynamic head-space) and injected in the gas chromatograph (figure 2). This method is known as head-space extraction (Kolb. 1997).

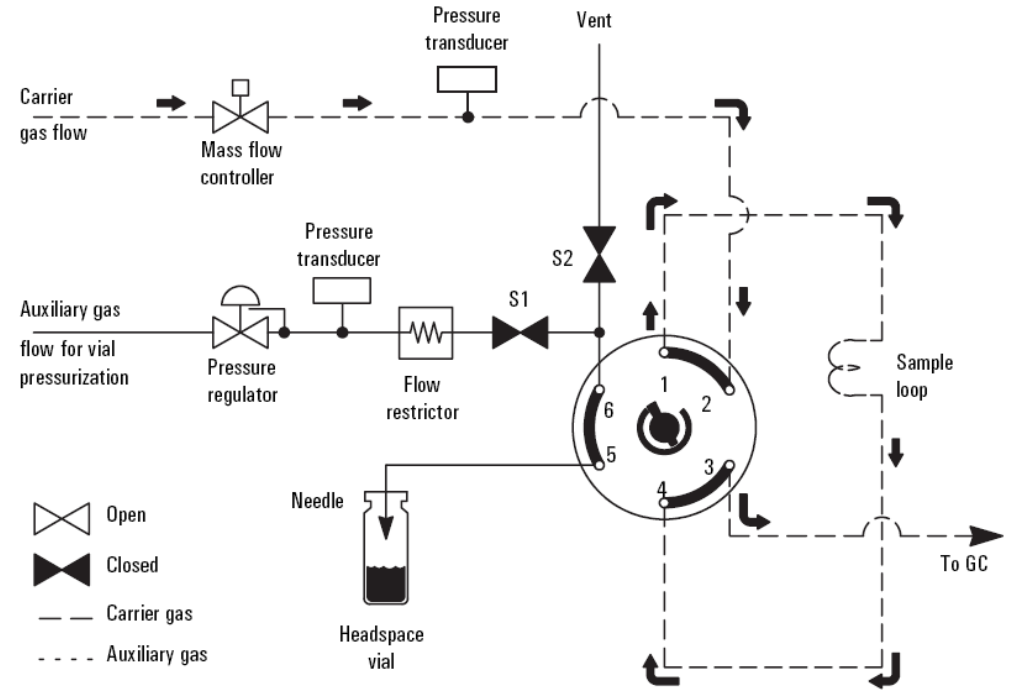

Fig. 2. Automatic sample injection into headspace (Agilent 2000)

\begin{tabular}{|c|c|c|}
\hline Method & Advantage & Disadvantage \\
\hline Head-space & $\begin{array}{l}\text { Allows direct evaluation of the } \\
\text { volatile compounds responsible } \\
\text { for the odor in foods at the } \\
\text { vapor phase. The analysis can } \\
\text { be performed quickly at a low } \\
\text { cost. }\end{array}$ & $\begin{array}{l}\text { Its use is restricted to samples } \\
\text { where the volatile compounds to be } \\
\text { evaluated are not retained in the } \\
\text { sample matrix.. }\end{array}$ \\
\hline Solvent extraction & $\begin{array}{l}\text { Ideal for the extraction } \\
\text { of compounds that are neither } \\
\text { lipids nor contain lipophilic } \\
\text { substances }\end{array}$ & $\begin{array}{l}\text { This technique is time consuming, } \\
\text { the analyte generally is more } \\
\text { diluted in the extraction and it is } \\
\text { hard to avoid some non-volatile } \\
\text { compounds in the extraction. }\end{array}$ \\
\hline Steam stripping & $\begin{array}{l}\text { Effective in the extraction } \\
\text { and condensation of volatile } \\
\text { compounds in water }\end{array}$ & $\begin{array}{l}\text { Produces a large number of } \\
\text { compounds by decomposition of } \\
\text { the pH and temperature }\end{array}$ \\
\hline Batch distillation & $\begin{array}{l}\text { Requires small sample } \\
\text { amounts, also, presents } \\
\text { excellent yield of the extraction } \\
\text { compounds }\end{array}$ & $\begin{array}{l}\text { The appearance of compounds that } \\
\text { are not part of the sample, from } \\
\text { different phenomena (hydrolysis, } \\
\text { oxidation, thermal reactions) }\end{array}$ \\
\hline
\end{tabular}

Table 4. Comparison of extraction methods (Martín del Campo. 2011, Gshaedler. 2004). 
The dynamic head-space technique is recommended, because thermodynamic equilibrium can be reached with all if the volatile compounds, decreasing the risk of not detecting important components in the samples. Moreover, it avoids having non-volatile compounds in the chromatograph (Núñez. 1986). To obtain better results, it is necessary to control the operating conditions, like agitation time, vial temperature, heat time, sample volume take in the head space, sample injected in the GC, etc. (Bylaite. 2006).

Studies of other alcoholic beverages like wine have used dynamic head-space to quantify and identify volatile compounds (Leino. 1993, Mestres. 1998). More than 45 volatile compounds have been identified, some of which had very low concentrations. Head space analysis is a good method for separating, quantifying, and identifying compounds and for determining the authenticity of the wines being tested (Etievant. 1986, Savchuk. 2001).

\subsection{Volatile compounds produced during the fermentation stage in the mezcal process}

The volatile compounds in mezcal and other alcoholic beverages have been determined in the final product (white and aged mezcal) (Molina. 2007, De León. 2006, Lachenmeier. 2006). However, to control the composition of volatile compounds in white mezcal, it is necessary to understand how each stage in the mezcal process influences the volatile compounds generation. More than $80 \%$ of the volatile compounds present in mezcal beverages are produced during fermentation (Lachance. 1995, Tellez-Mora. 2001), so it is important to understand how the different volatile compounds are produced and which factors influence the amount and types formed. In the case of mezcal there have been few studies are available related to the synthesis of the volatile compounds during fermentation (Segura. 2010, Alcázar-Valle. 2011). The next section will be explained the methodologies used to evaluate the volatile compounds.

\subsubsection{Batch distillation for quantifying volatile compounds in fermented agave juice}

Arellano, et al. (2008) used batch distillation to evaluate the volatile compounds in fermented agave juice. The agave juice was distilled prior to the chromatographic evaluation. Their procedure was as follows: add $5 \mathrm{~mL}$ of agave juice to $5 \mathrm{~mL}$ of water in a boiling flask, then connect the flask to micro distiller with a vigreaux column to increase the reflux, next the vapor is condense by a refrigerant at $0^{\circ} \mathrm{C}$, and the first $5 \mathrm{~mL}$ are recover. With this method, is recovered $5 \mathrm{~mL}$ volume of the sample separate to the color, sugars, fiber and other non-volatile compounds. Next, $0.5 \mu \mathrm{L}$ of distilled agave juice is injected into a Hewlett Packard GC, 6890 series, using a DB-wax chromatography column $30 \mathrm{~m} . \times 0.25 \mathrm{~mm} \times 0.25 \mu \mathrm{m}$ with an ionization flame detector (Arellano. 2008). The volatile compounds identified and quantified were: acetaldehyde, ethyl acetate, methanol, ethanol, 1-propanol, isobutanol, amyl alcohol and ethyl lactate using external standards. This methodology was used to compare the volatile compounds produced for different indigenous tequila yeast at two fermentation temperatures. The results showed that different volatile compounds were produced depending on the yeast strain and the fermentation temperature.

Batch distillation methodology has been applied in other works to evaluate the variability of volatile compounds produced in spontaneous fermentation. This has proved to be a good method to for evaluating the fermentation stage, and it is now used in the quality control systems of some tequila factories (Arellano. 2009). 
It is important to know that the distilled sample contain high level of water, because the ethanol produced is about $8 \%$ by volume $(63 \mathrm{~g} / \mathrm{L}$ of ethanol). The water will contribute to column stationary phase degradation and thus the column's life span. Using this technique, it is possible to determine the levels of those volatile compounds which are governed by the Mexican quality laws for mezcal (SCFI 1997), tequila (NOM-006-SCFI-1994 1994) and sotol (NOM-159-SCFI-2004 2004) during the fermentation stage, prior to distillation. This enables the distillers to modify the distillation conditions to ensure that those compounds are at the appropriate levels.

\subsubsection{Solvent extraction for quantify volatile compounds in fermented agave juice}

Pentane is a non-polar solvent commonly used because extract ethanol at low levels, and it has an affinity for esters and fatty acids. Dichloromethane is often used because is less dangerous than pentane and can be easily purified, but is moderately polar. While there are no studies for mezcal covering this method for evaluating the volatile compounds in fermented agave juice, it has been used successfully for tequila (Martín del Campo. 2011, Prado-Jaramillo. 2002, Pinal. 2001).

The procedure used was as follows: $15 \mathrm{~mL}$ of a mixture of pentane and dichloromethane 3:1 $\mathrm{v} / \mathrm{v}$ was added to $70 \mathrm{~mL}$ of fermented agave juice and agitated for $5 \mathrm{~min}$. This solution was centrifuged to separate two phases. The supernatant was recovered and sodium sulphate was added in order to remove the water. Then, the extract was concentrated in a Kuderna Danish flask with a vigreaux column. The system was heated to $40^{\circ} \mathrm{C}$ in a water bath, and the solution was evaporated up to $0.4 \mathrm{~mL}$ sample remain. Finally, it was injected in a GC-MS Hewlett Packard 5890 series II to separate the compounds using a DB-wax column $30 \mathrm{~m} . \mathrm{x}$ $0.25 \mathrm{~mm} \times 0.25 \mu \mathrm{m}$. The total ion chromatograms were obtained with an electron impact mode ion source working at $70 \mathrm{eV}$ and tracked at $1.6 \mathrm{scans} / \mathrm{sec}$. The compound identifications were made with a 5970 MS chemstation G1034 C version C 01.05, comparing the spectrums with a Wiley library or with the Kobats index (Prado-Jaramillo. 2002). To quantify the volatile compounds, the samples were injected again in a Gas Chromatograph with Flame Ionization Detector (GC-FID), using the same column and conditions as were used in Gas Chromatograph with Mass Detector (CG-MS) explained above.

Using this method 29 higher alcohols, 11 aldehydes, 16 organic acids, 18 ketones, 58 esters, 9 phenols, 12 furans, 26 terpenes, 4 sulfuric compounds, 5 hydrocarbons, 2 lactones, 2 pyrans and 15 others compounds were identified. In total, 207 volatile compounds were found. The higher alcohols had the high concentration and the esters were the most diverse compounds found (Prado-Jaramillo. 2002).

The solvent extraction methodology is a powerful tool for identifying and quantifying the volatile compounds in fermented agave juice, but it requires sufficient laboratory equipment and enough time to process all the information.

\subsubsection{Headspace for quantify volatile compounds in fermented agave juice}

The head-space methodology to analyze the volatile compounds in agave juice is another technique that can be used, since it does not require handling of samples and it is feasible to add solids in the vial which can influence in the sample volatile composition. 
As was mentioned previously, in producing mezcal from fermented agave juice, the agave bagasse is added to the fermentation tanks during the fermentation stage. If only a liquid sample is taken, this will affect the composition. Therefore it is necessary to take a sample that contains solids in the same proportion as was in the wort (agave bagasse - water) at initial fermentation (Arellano. 2009).

To separate the volatile compounds, the sample quantity must be large enough that the minor components can be detected. With many samples, the more volatile compounds could fill the head space, making it difficult to detect the minor volatiles. Vials of different volumes can be used, depending on the separation desired. In the head space system it is necessary to heat the sample to vaporize the volatile compounds. The temperature must be regulated to obtain the kind of compounds that are wanted. With low temperatures, only the most volatile compounds will be vaporized, and if the temperature is near to the boiling point of water, a high level water vapor will get into the chromatography column.

Head-space methodology was used to evaluate samples of agave juice. Samples weighing 2 grams were put in a $20 \mathrm{~mL}$ vial, then they were put it in a head-space HP7694E programmed for these conditions: vial temperature $80^{\circ} \mathrm{C}$, loop temperature $110^{\circ} \mathrm{C}$, transfer line $115^{\circ} \mathrm{C}$, vial equilibrium time $5 \mathrm{~min}$, pressurization $2 \mathrm{~min}$, loop filling $0.2 \mathrm{~min}$, loop equilibrium time $0.5 \mathrm{~min}$, injection time $1 \mathrm{~min}$, injection volume $1 \mathrm{~mL}$. The GC HP6890 with a FID detector was programmed as follow: the oven sloop was $55^{\circ} \mathrm{C}$ for $5 \mathrm{~min}$, next increased at rate for $5^{\circ} \mathrm{C} / \mathrm{min}$ to reach $160^{\circ} \mathrm{C}$, next increased $25^{\circ} \mathrm{C} / \mathrm{min}$ to $220^{\circ} \mathrm{C}$, finally the temperature was maintained for $8 \mathrm{~min}$. The chromatography column was an HP Innowax 60 $\mathrm{m} \times 0.32 \mathrm{~mm} \times 0.25 \mu \mathrm{m}$. The injector and detector temperature were $250^{\circ} \mathrm{C}$. The injection used a 1:50 split. The analysis time was $45 \mathrm{~min}$, including the extraction by head-space and GC.

The volatile compounds quantified were: acetaldehyde, ethyl acetate, methanol, 1-propanol, isobutanol, amyl alcohols, isobutanol, ethyl valerate, ethyl lactate, ethyl caprylate, ethyl caproate, 2-furfuraldehyde and 2-phenyl ethanol (figure 3). Two yeasts isolated from fermentation stage in the mezcal processes were used to evaluate the volatile production in different agave juice species (table 5 and table 6). Both yeasts are Kluyveromyces marxianus and the volatile compounds were produced at different levels, those results show the importance to select the yeast used in the process.

\begin{tabular}{cccccc}
\hline & \multicolumn{5}{c}{ Juice } \\
Compound & A. & A. & A. & A. & A. \\
& angustifolia & cupreata & durangensis & salmiana & tequilana \\
\hline Acetaldehyde (ppm) & $296.03 \pm 3.32$ & $305.26 \pm 0.50$ & $23.08 \pm 1.71$ & $54.23 \pm 1.54$ & $39.84 \pm 0.16$ \\
Ethyl acetate (ppm) & $58.12 \pm 7.83$ & $22.72 \pm 2.76$ & $155.03 \pm 6.02$ & $80.32 \pm 0.43$ & $53.65 \pm 1.34$ \\
1-propanol (ppm) & $20.98 \pm 4.32$ & $35.51 \pm 0.41$ & $14.28 \pm 0.28$ & $22.84 \pm 1.65$ & $15.89 \pm 0.46$ \\
Isobutanol (ppm) & $316.91 \pm 5.432$ & $116.63 \pm 1.90$ & $113.92 \pm 14.86$ & $267.15 \pm 12.43$ & $136.24 \pm 4.41$ \\
Amylic alcohol & $242.67 \pm 13.26$ & $170.36 \pm 2.54$ & $90.06 \pm 0.05$ & $170.22 \pm 22.31$ & $157.95 \pm 2.90$ \\
(ppm) & 24.67 &
\end{tabular}

Table 5. Volatile compounds produced during mezcal fermentation using different agave juices with the yeast OFF1 (K. marxianus) 


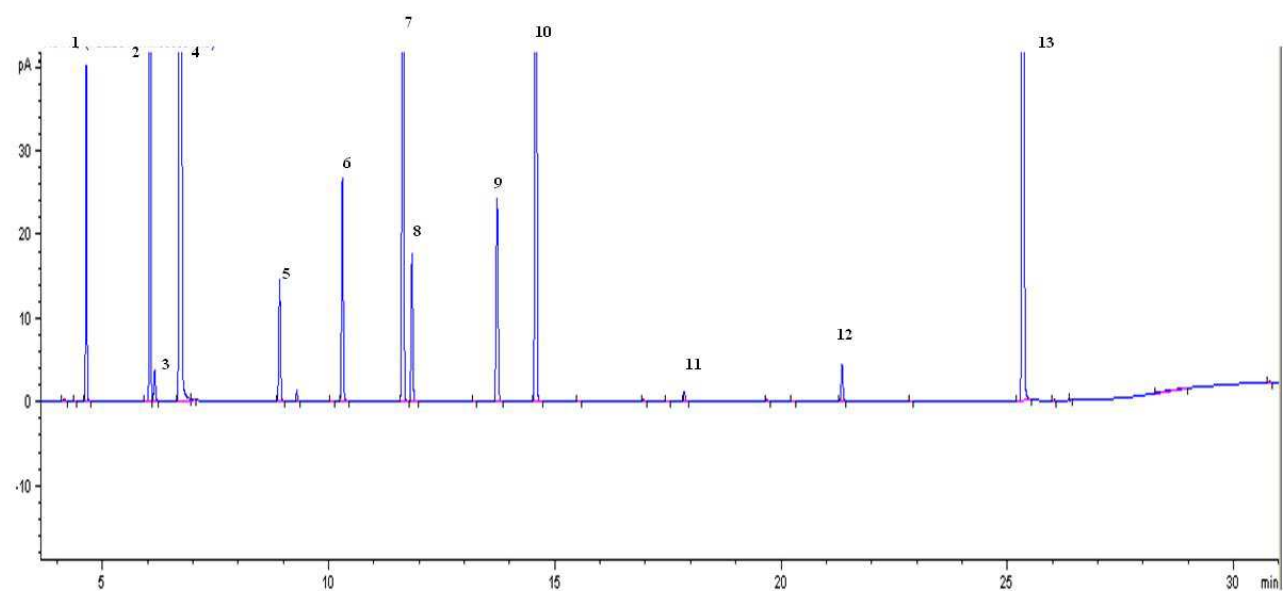

Fig. 3. Gas chromatogram of the volatile compounds in a fermented agave juice using headspace injection system: (1) Acetaldehyde, (2) ethyl acetate, (3) methanol, (4) ethanol, (5) 1-propanol, (6) Isobutanol, (7) ethyl valerate, (8) 1-butanol, (9) amyl alcohols, (10) ethyl caproate, (11) ethyl lactate, (12) 2-furfuraldehyde, (13) ethyl caprate.

Table 1 shows the Mexican law governing the contents of mezcal, which specifies the concentration of higher alcohols and methanol. The law for tequila specifies the levels of acetaldehyde, 2-furfuraldehyde and esters. Using head-space methodology it is possible to evaluate during the fermentation stage the volatiles compounds according to the Mexican laws for all alcoholic distilled agave beverages (NOM-006-SCFI-1994 1994, Arellano. 2009). It is also possible to quantify other compounds, but that requires changing the head-space and GC-FID conditions.

Compound

\begin{tabular}{cccccc}
\hline Acetaldehyde (ppm) & $74.95 \pm 11.14$ & $82.05 \pm 0.04$ & $30.49 \pm 6.10$ & $84.23 \pm 9.21$ & $33.73 \pm 1.02$ \\
Ethyl acetate (ppm) & $88.85 \pm 6.81$ & $34.01 \pm 0.05$ & $205.93 \pm 0$ & $100.71 \pm 19.86$ & $60.82 \pm 5.49$ \\
1-propanol (ppm) & $19.73 \pm 0.82$ & $14.32 \pm 2.93$ & $16.40 \pm 1.89$ & $24.12 \pm 4.65$ & $16.51 \pm 0.30$ \\
Isobutanol (ppm) & $186.79 \pm 2.06$ & $30.89 \pm 6.30$ & $70.74 \pm 8.12$ & $235.84 \pm 19.21$ & $66.93 \pm 1.94$ \\
$\begin{array}{c}\text { Amylic alcohol } \\
\text { (ppm) }\end{array}$ & $171.79 \pm 3.05$ & $88.76 \pm 0.05$ & $101.43 \pm 0.05$ & $287.83 \pm 6.73$ & $109.20 \pm 9.79$ \\
\hline
\end{tabular}

Table 6. Volatile compounds produced during mezcal fermentation using different agave juices with the indigenous yeast SLP1 (K. marxianus).

Others studies using head space methodology have observed a difference in the volatile composition based on both agave species and yeast species (Segura. 2010, Alcázar-Valle. 2011). Terpenes have been found in mezcal and could be used to identify which agave was used as the raw material, but under the head-space conditions they could not be detected (Alcázar Valle. 2011). It is necessary change the conditions to look other volatile compounds that are important for these beverages (Molina. 2007). The head-space methodology can have less sample handling time and may be less costly than the others methodologies. 


\section{Conclusion and perspectives}

The chromatographic systems to evaluate the fermented wort are a powerful methodology to indentify and quantify volatile compounds. The correct selection of the volatile compounds analysis is very important because the time and equipment needed is different for each methodology. Batch distillation is the most common system used in a laboratory since it is easy and cheap. However the life span of the chromatography column can be reduced by samples that have high water content. The solvent extraction allows obtain many volatile compounds, but is necessary a GC-MS to identify the desired compounds and GC-FID to quantify them, it is needed much sample to the extraction and also the solvents are dangerous to the operator and to the environment. With the dynamic head-space methodology is possible to identify and quantify the volatile compounds in the Mexican laws regulated and other more, but it is better has an automatic equipment to avoid the sample handling.

Finally, there are other methodologies that can be used to evaluate the volatile composition in fermented agave juice for the mezcal production, like the membranes to solid phase micro extraction (SPME). This method avoids separating the specific compounds, but it is necessary find the correct conditions in order to obtain the desired results.

\section{References}

Agilent (2000). Agilent 7694 Headspace Sampler. Operating Manual.

Alcázar Valle., E. M. (2011). Capacidades Fermentativas y Generación de volátiles de cepas de levadura aisladas en diferentes estados productores de mezcal. In: Biotecnología Industrial. Pp. 101. Guadalajara: Centro de Investigación y Asistencia en Tecnología y Diseño del Estado de Jalisco.

Arellano, M., Pelayo, C., Ramã-Rez, J. S. \& Rodriguez, I. (2008). Characterization of kinetic parameters and the formation of volatile compounds during the tequila fermentation by wild yeasts isolated from agave juice. Journal of Industrial Microbiology \& Biotechnology, 35, 835-841.

Arellano M., H. E. (2009). Asesoría Técnica Del Proceso De Elaboración De Mezcal En 2 Fábricas En El Estado De Durango y 2 Fábricas En El Estado de Guerrero. Pp. 65. Guadalajara: CIATEJ.

Arrizon., G., J., (2001). Efecto de la concentración de azúcar y la adición de nitrógeno sobre el producto de fermentación del tequila. In: Centro Universitario de Ciencias Exactas e Ingenierías Pp. 119-125. Guadalajara: Universidad de Guadalajara.

Benn, S. M. \& Peppard, T. L. (1996). Characterization of Tequila Flavor by Instrumental and Sensory Analysis. Journal of Agricultural and Food Chemistry, 44, 557-566.

Berry, D. R., Watson, D. C. (1987). Volatile compounds production in alcoholic beverages. In: Yeast biotechnology. Ed. Berry, D.R., Russell, I., Stewart, G. London: Allen and Unwin.

Bylaite., E., Meyer., Anne S., (2006). Characterization of volatile aroma compounds of orange juices by three dynamic and static headspace gas chromatography techniques. Eur Food Res Technol, 222, 176-184. 
Gschaedler, M., Córdova, C. J., Díaz, M. D., Herrera, L. J., Arellano, P. M., Arrizon, G. J., Pinal, Z. L. (2004). Ciencia y Tecnología del Tequila Avances y Perspectivas. México, CIATEJ.

De León., R., A., González., Hernández., L., Barba., De La Rosa., A., P., Escalante., Minakata., P., López., M., G., (2006). Characterization of volatile compounds of Mezcal an Ethnic Alcoholic Beverage Obtained from Agave salmiana. Journal of Agricultural Food Chemestry, 54, 1337-1341.

Etievant., P. (1986). Wine Analysis: Study and Comparison of Techniques Developed for the Study of Volatile Constituents. Chromatographia, 21, 379-386.

King., A., Dickison., J. R., (2000). Biotransformation of monoterpene alcohols by Saccharomyces cerevisiae, Torulaspora delbrueckii and Kluyveromyces lactis. Yeast, 16, 499-506.

Kolb, B. and Ettre, L. (1997). Static Headspace-Gas Chromatography Theory and Practice. New York, Wiley-VCH.

Lachance., M. A. (1995). Yeast communities in a natural tequila fermentation. Antonie van Leeuwenhoek, 68, 151-160.

Lachenmeier, D. W., Sohnius, E., Attig,R. López, M. (2006). Quantification of Selected Volatile Constituents and Anions in Mexican Agave Spririts (Tequila, Mezcal, Sotol, Bacanora). Journal of Agricultural and Food Chemistry, 54, 3911-3915.

Lappe., O. P., Moreno Terrazas R, Arrizón Gaviño J., Herrera Suárez. T, García Mendonza A., Gshaedler Mathis A (2008). Yeasts associated with the production of Mexican alcoholic nondistilled and distilled Agave beverages. Federation of European Microbiological Societies, 8, 1037-1052.

Leino., M., Francis., Leigh I., Kallio., Heikki., Williams., Patrick J., (1993). Gas chromatographic headspace analysis of Chardonnay and Semillon wines after thermal processing. Z. Lebensm Unters Forsch, 197, 29-33.

López., M. G., Mancilla., Margalli N. A., Mendoza Diaz., G., (2003). Molecular Structures of Fructans from Agave tequilana Weber var. azul. Journal of Agricultural and Food Chemistry, 51, 7835-7840.

Martín Del Campo., S., Hernández., Gómez., Héctor E., Gutiérrez Humberto., Escalona Hector., Estarrón Mirna., Cosío Ramírez Ricardo., (2011). Volatile composition of tequila. Evaluation of three extraction methods. CyTA-Journal of Food, 9, 151159.

Mestres., M., Busto., O, Guasch., J., (1998). Headspace solid-phase microextration analysis of volatile sulphides and disulphides in wine aroma. Journal of Chromatography A, 808, 211-218.

Molina., G., J.,A., Botello., Alvárez., J., E., Estrada., Baltazar., A., Navarrete., Bolaños., J.,L., Jiménez., Islas., H., Cárdenas., Manríquez., M., Rico., Martínez., R., (2007). Compuestos Volátiles en el Mezcal. Revista Mexicana de Ingeniería Química, 6, 4150.

Moreno., A., M., Polo., C., (2009). Wine Chemistry and Biochemistry. USA, Springer.

NOM-006-SCFI-1994 (1994). Bebidas alcohólicas - Tequila especificaciones. (edited by SCFI). México D. F.: SCFI. 
Nom-159-Scfi-2004 (2004). Bebidas Alcohólicas-Sotol-Especificaciones Y Métodos De Prueba. (edited by SCFI). México D. F.

Núñez., A. J. (1986). Headspace Methods for Volatile Components of Grapefruit Juice. Chromatography, 21, 44-48.

Nykanen., L. (1983). Aroma of Beer, Wine and Distilled Alcoholic Beverages. Berlin, Kluwer Academia Publisher.

Peña., A., A., Díaz., L., Medina., A., Labastida., C., Capella., S., Vera., L., (2004). Characterization of three Agave species by gas chromatography and solid-phase microextraction-gas chromatography-mass spectrometry Journal of Chromatography A, 1027, 131-136.

Pinal, L. (2001). Influencia del tiempo de cocimiento sobre la generación de compuestos organolépticos en las etapas de cocimiento y fermentación de la elaboración del tequila. In: CUCEI. Pp. 145. Guadalajara: Universidad de Guadalajara.

Prado-Jaramillo (2002). Estudio de los compuestos volátiles en las diferentes etapas del proceso de producción del tequila. In: CUCEI. Pp. 110. Guadalajara: Universidad de Guadalajara.

Sagarpa (2004). Plan Rector Sistema Nacional Maguey-Mezcal.

Savchuk., S. A., Vlasov., V. N., Appolonova., S. A., Arbuzov., V. N., Vedenin., A. N., Mezinov., A. B., Griogor'yan., B. R., (2001). Application of Chromatography and Spectrometry to the Authentication of Alcoholic Beverages. Journal of Analytical Chemistry, 56, 214-231.

SCFI (1997). Bebidas Alcohólicas, Mezcal-Especifícaciones. In: NOM-070-SCFI-1997.

SCFI (2004). Norma Oficial Mexicana NOM-168-SCFI-2004, Bebidas alcohólicas-BacanoraEspecificaciones de elaboración, envasado y etiquetado. (edited by ECONOMÍA, S. D.). México D. F.: SCFI.

Segura, L. E. G. (2010). Identificación y Caracterización por Métodos Moleculares de Levaduras Aisladas del Proceso de Elaboración del Mezcal en el Estado de Oaxaca. In: Posgrado Interinstitucional en Ciencia y Tecnología. Pp. 177. Guadalajara: Centro de Investigación y Asistencia en Tecnología y Diseño del Estado de Jalisco.

Skoog D. A., Holler, J. Nieman T. (1992). Principios de Análisis Instrumental Pp. 1028. Madrid, Mc Graw Hill.

Takoi., K., Koie., Koichiro., Itoga., Yutaka., Katayama., Yuta., Shimase., Masayuki., Nakayama., Yasuyuki., Watari., Junji (2010). Biotransformation of Hop-Derived Monoterpene Alcohols by Lager Yeast and Their Contribution to the Flavor of Hopped Beer. Journal of Agricultural and Food Chemistry, 58, 5050-5058.

Tellez-Mora, P. (2001). Análisis de las variables que influyen en la síntesis de metanol en la producción del tequila, durante las etapas de cocimiento y fermentación. In: CUCEI. Pp. 98. Guadalajara: Universidad de Guadalajara.

Valenzuela., A. (2007). Signos distintivos en los alimentos y bebidas mexicanas: una propuesta a partir de la denominación de origen mezcal. Revista Salud Pública y Nutrición, 8, 1-16. 
Vázquez., G., J., Cházaro., M., Hernández., Vera., G., Berrios., Flores., E., Vargas., Rodríguez., Y., (2007). Agaves del Occidente de México. (edited by BIODIVERSIDAD, S. D. F. D.). 


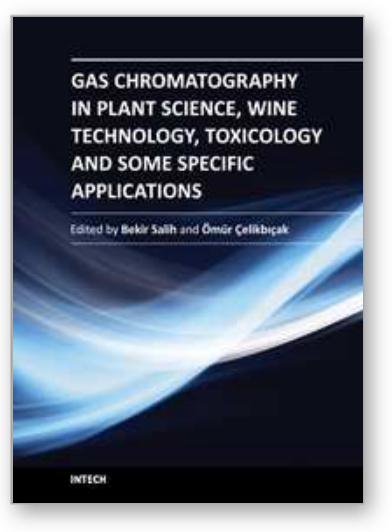

\author{
Gas Chromatography in Plant Science, Wine Technology, \\ Toxicology and Some Specific Applications \\ Edited by Dr. Bekir Salih
}

ISBN 978-953-51-0127-7

Hard cover, 346 pages

Publisher InTech

Published online 29, February, 2012

Published in print edition February, 2012

The aim of this book is to describe the fundamental aspects and details of certain gas chromatography applications in Plant Science, Wine technology, Toxicology and the other specific disciplines that are currently being researched. The very best gas chromatography experts have been chosen as authors in each area. The individual chapter has been written to be self-contained so that readers may peruse particular topics but can pursue the other chapters in the each section to gain more insight about different gas chromatography applications in the same research field. This book will surely be useful to gas chromatography users who are desirous of perfecting themselves in one of the important branch of analytical chemistry.

\title{
How to reference
}

In order to correctly reference this scholarly work, feel free to copy and paste the following:

Melchor Arellano, Anne Gschaedler and Montserrat Alcazar (2012). Major Volatile Compounds Analysis Produced from Mezcal Fermentation Using Gas Chromatography Equipped Headspace (GC-HS), Gas Chromatography in Plant Science, Wine Technology, Toxicology and Some Specific Applications, Dr. Bekir Salih (Ed.), ISBN: 978-953-51-0127-7, InTech, Available from: http://www.intechopen.com/books/gaschromatography-in-plant-science-wine-technology-toxicology-and-some-specific-applications/major-volatilecompounds-analysis-produced-from-mezcal-fermentation-using-gas-chromatography-equippe

\section{INTECH}

open science | open minds

\author{
InTech Europe \\ University Campus STeP Ri \\ Slavka Krautzeka 83/A \\ 51000 Rijeka, Croatia \\ Phone: +385 (51) 770447 \\ Fax: +385 (51) 686166 \\ www.intechopen.com
}

\author{
InTech China \\ Unit 405, Office Block, Hotel Equatorial Shanghai \\ No.65, Yan An Road (West), Shanghai, 200040, China \\ 中国上海市延安西路65号上海国际贵都大饭店办公楼405单元 \\ Phone: +86-21-62489820 \\ Fax: +86-21-62489821
}


(C) 2012 The Author(s). Licensee IntechOpen. This is an open access article distributed under the terms of the Creative Commons Attribution 3.0 License, which permits unrestricted use, distribution, and reproduction in any medium, provided the original work is properly cited. 